\title{
The New Great Trek: The Root Causes of the Influx of Refugees from Syria and Iraq to Europe
}

\author{
Sherko Kirmanj ${ }^{1 *}$, Talibu Oladimeji ${ }^{2}$, Ahmad Bashawir bin Haji Abdul Ghani ${ }^{3}$ \\ ${ }^{1}$ Visiting Senior Lecturer, School of International Studies, University Utara Malaysia, MALAYSIA \\ ${ }^{2} \mathrm{PhD}$ Candidate, School of International Studies, University Utara Malaysia, MALAYSIA \\ ${ }^{3}$ Dean, School of International Studies, University Utara Malaysia, MALAYSIA \\ *Corresponding Contact: \\ Email: kirmanj@uum.edu.mu
}

\begin{abstract}
In 2010, a wave of political uprisings blew across the Middle East and North Africa (MENA), the result of which persists in some countries like Syria, Libya, Yemen and Egypt. That of Syria is unique given the number of people killed as well as the number of refugees that fled the country. Also, since 2003, people have been fleeing Iraq to other parts of the world. In an attempt to provide answers for such demographic mobility, this research examines those factors that impelled the Syrians and Iraqis to embark on such perilous journey to Europe in 2015, in particular. One of the factors, according to the findings of the study, is the total loss of hope for peace and change in Syria and Iraq. Thus, the article suspects that if the present political debacle in Syria and Iraq continues, the refugee will maintain their influx to Europe in 2016 and beyond.
\end{abstract}

Keywords: Refugees, Influx of Refugees, enmasse migration, refugee boom

$12 / 20 / 2016$

Source of Support: Nil, No Conflict of Interest: Declared

How to Cite: Kirmanj S, Oladimeji T and Ghani AB. 2016. The New Great Trek: The Root Causes of the Influx of Refugees from Syria and Iraq to Europe $A B C$ Journal of Advanced Research, 5, 91-100.

This article is is licensed under a Creative Commons Attribution-NonCommercial 4.0 International License.

Attribution-NonCommercial (CC BY-NC) license lets others remix, tweak, and build upon work non-commercially, and

although the new works must also acknowledge \& be non-commercial.

\section{INTRODUCTION}

The refugee problem is a cankerworm that has eaten deep into the social fabric of the contemporary global system. Its recurrent nature has put much pressure on the resources available to maintain and mitigate the incidence by the United Nations High Commissioner for Refugee (UNHCR).The accumulated socio-political problems in Syria and Iraq have thus far led to the refugee crisis in both the Middle East and Europe. In 2015, the spate of refugee mass movement to Europe was unprecedented in the history of the region. Scholars, pundits, politicians, and media have begun to search for answer(s) for such enmasse migration to Europe from Iraq and Syria as well as other countries. The contemporary problem of refugees seems to be irresolvable given its persistence and continuity. What became a flash in the Second World War has become the permanent feature of the global social terrain. The most 
daunting of all refugee issues is that of Syria and Iraq. The last wave of refugees out of Iraq started in the wake of 2003 while Syria's began in 2011 in the beginning of Arab uprisings when the Syrian people's peaceful protest and demonstrations turned violence by the end of the year. Those who started the awakening, most especially from Tunisia, did not foresee it would become intractable to the extent of having such multiplying effect on the political and social terrain of the Middle East and hence the world in general. The Arab uprisings is the principal culprit in the contemporary refugee predicament that the world witnesses. It needs to be stated here that the uprising was not staged in bad faith. Nevertheless, what we are insinuating here is that if there are no Arab uprisings the present refugee situation may not occur. Put differently; the global "refugee boom" would not have witnessed such drastic demographic mobility the world ever seen since 1945 (UNHCR, 2014).

The reasons behind the Arab Spring are out of the scope of this study. Whatever may be the reasons, the contemporary refugee disaster in the Middle East cannot witness a reversal in the foreseeable future. In the refugee debacle, Syrians and Iraqis are the most affected and produced most of the refugees. It should be stated here that countries like Libya, Yemen, Somalia and Sudan also produced large number of refugees. Theirs are comatose in the number of refugee from Syria and Iraq. By 2014 alone, Turkey received 1.56 million, Lebanon, 1.15 million, Jordan, 623,100, Kurdistan Region of Iraq, 234,000 and Egypt 138,400 Syrian refugees. Besides, over 175,000 Syrians refugees also launched asylum application in Europe in the same year (UNHCR, 2014).

In 2015, Syria and Iraq became the principal sources of refugees to Europe and other parts of the world. The Internal Displacement Monitoring Centre (IDMC) in Geneva announced that the number of displaced Iraqis within Iraq reached 4 million in mid-June 2015, compared to 3.5 million in December 2014 (IDMC 2015). However, by the end of 2015 the number dropped to 3.3 million (IDMC 2016). In Syria, 7.6 million persons were displaced within Syria - an increase from a long-held UN estimate of 6.5 million - as well as 4 million Syrian refugees abroad (UNHCR, 2015).

The lingering questions are: why most of the refugees decided to leave neighboring countries to Europe the way they did in 2015? Could there be any empirical explanation to justify the constant mobility of the multitude of Syrians and Iraqis from neighboring countries to Europe in 2015? In answering these questions, this article divides into sections with each devoted to providing the response to the issues raised in the research. In this case, the first one looks at endogenous factors in both countries that made refugee crisis inevitable while the second section delves into end of spectrum factors and section three concludes the research.

\section{ENDOGENOUS FACTORS}

As initially conceived in the introductory section, providing justification for the mass demographic mobility may be difficult for researchers. Given the fact that the internal political climate in virtually all Arab countries had been consistently autocratic in character and nature may tempt one to commit intellectual error if the contemporary refugee problem is attributed to it. There had been a modicum of peace and stability, at least on the surface, in the whole of Arab countries before 2010, the beginning of Arab uprisings. What might account for such relative peace and stability enjoined by Arab states under the autocratic rule is diverse, ranging from repression to relative economic gain and prosperity, most especially in the Arab Gulf region (Cockburn, 2016). While this may be difficult to explain is the fact that the autocratic regime is not limited to Arab countries. It is a structural feature of governance in most developing countries of Africa, Asia, and Latin America (Garfinkle, 2013). And where this occurs, it does not necessarily bring about anarchy and chaos. 
Thus, with the exception of Iraq, which plagued in civil war for eight years before the Arab uprisings, most countries in the Middle East were enjoying relative peace compared to some other countries in sub-Saharan African. Therefore, if these countries were enjoying some level of prosperity and peace, why did the uprising occur the way it did? For the purpose of analysis, it is of interest to note that the present socio-political debacle experience in Syria today can be primarily linked to the Arab uprisings that started in Tunisia in 2010 (Taub, 2015). The wave of uprising radiated to Egypt, Libya and hence to Yemen and Syria. One needs to stress that the wave was not premeditated to spread to all Arab countries the way it did. The masses in the other Arab countries only utilized the opportunity to rise against their governments because of years of repression, oppression, family succession and corruption (Anderson, 2011; Al Hendi, 2011).

However, as soon as the Syrian people came to the streets the government forces brutally suppressed them which later resulted in the civil war. The Syrian authorities continued its policy of violence against the opposition groups and civilians living in oppositioncontrolled areas. Human Rights Watch (HRW) documented five years (2011-2016) of human rights violations by Syrian government security forces and officials which included extrajudicial executions and other unlawful killings of civilians (HRW, 2016a). In the same report, HRW has also documented extrajudicial and summary executions by opposition forces. It stated that torture and maltreatment in opposition-run detention facilities and use of child soldiers is widespread by opposition forces.

In the Iraqi case, the United States (US) invasion of Iraq in 2003 resulted in the removal of Saddam's tyrannical regime. Such removal led to the cosmetic development in the areas of democracy and political pluralism. Such change resembled top-down democratization project. However, democratization reinforced sectarian and ethnic affiliation as Iraqis voted according to their sects (Kirmanj, 2013: 199). Indeed, the introduction of elections failed woefully to cement Iraqi social fabric as, within two years from the invasion, Iraq was well into the civil war that is continuing even after three rounds of national elections. By early 2016, documented civilian and combatant deaths from violence are almost 250,000 (Iraq Body Count, 2016). The US invasion of Iraq is reaching its logical conclusion - not the consolidation of democratic, secular state but the disintegration of Iraq. Thus, the Iraqis who resisted leaving during previous crises are now embarking on the country's next great wave of emigration. Such disappointments, the failure of top-down democratization in Iraq and bottom-up democratization in Syria, added more to the worsening case of refugees by 2015.

Although, the regime in Iraq may not involve in unleashing terror on people bluntly, but the government failure to wrest the control of large parts of Iraq from Islamic State in Iraq and Syria (ISIS) made people susceptible to ISIS onslaught. Also, Iraqi Shi 'a-led central government also seems to favor sectarianism in its dealings with the principal components of Iraqi society, especially the Sunnis and Kurds. The crackdown of Shi 'a militias under the auspices of the Iraqi government, of Sunnis including civilians on the one hand, and ISIS onslaught of minority religious and ethnic groups such as Christians, Yezidis, and Kurds on the other hand, resulted in mass internal displacement and migration (HRW, 2016b; Nichols, 2015; Bradley, 2014; Bradley and Nabhan, 2013). Hence, Iraqis, most especially religious and ethnic minority members, are of the conviction that it is better to leave Iraq and live elsewhere where human dignity and security are guaranteed. Indeed, the last decade has seen the mass migration of Christians out of Iraq. If the trend continues, we may well see the disappearance of Christians in Iraq if not in the entire Middle East countries (Griswold, 2015; Sinder, 2015). 
The breakdown of social fabric is added more to the already worsened political stalemate. Christian and Yezidi communities became a subject to all sorts of atrocities, forcible conversion and enslavement by ISIS (Mamouri, 2014; Mamouri, 2015; Economist 2014). But more worrisome is the claims made by Christians, Yezidis, Kurds and other minority groups who said in interviews with Los Angeles Times and The Guardian that some Sunni Arab residents either participated as ISIS fighters overran their towns and villages, or looted non-Sunni Arab homes and businesses after the ISIS militants took over (Bengali, 2014; Hawramy, 2015; Wintour, 2016). Therefore, the formerly relative peaceful coexistence exhibited among the various factions who were neighbors is no more there. In this case, the level of suspicion and distrust among the neighbors is very alarming, and this makes returning home a doubtful exercise.

Related to the above is the sectarian and ethnic cleansing, a policy implemented by most warring factions, either in Iraq or Syria. It is not just a random act of violence committed by some military factions; it is a systematic policy. An Iraqi, Tahir Abdul Hamid, stated in an interview "we feel like we are living in a jungle, where the strong eat the weak." He added, "If I had the ability to leave already, and enough money, I would have left" (Arango, 2015). Also, HRW reported that between March and April 2015, Iraqi government-backed Shi 'a militias carried out widespread destruction of homes and shops around the city of Tikrit in violation of the laws of war (HRW, 2015). This scenario thus disenchanted people from going back to Iraq from refugee camps while those inside also lost hope in staying in the country. The same hopelessness also occurred in Syrian case.

It should be stressed further that most people in Iraq and Syria are tired of protracted civil war. Initially, there were hope and belief that the civil war might subside one day. The years of prolonged civil war dashed people's hope and thereby resulting in making swift action. Such loss of hope might have been a coincidence that resulted in mass movement of people to Europe in 2015 after so many years in waiting for the conflicts to subside. Even if such peaceful atmosphere would prevail, it takes long time given the scale and magnitude of destruction that has taken place in both countries.

Given the complicated enmity that exists among various groups, there is public conviction that there is the possibility of reoccurrence even if the present stalemate remains calm. In this manner, the loss of close relations and relatives has made some people see their country as being hopeless and therefore of no value to them. Families and friendship that supposed to be a connecting factor to one's root are lost to the years of civil conflicts in both countries, and this made some people think of relocating to a better environment where their life will be more secured.

\section{EXOGENOUS FACTORS}

The Iraqis and Syrians began to enmesh in political trouble in 2003 and 2011, respectively. The sudden breakdown of order in Iraq as a result of the leadership vacuum left by toppling Saddam Hussein's regime, dismantling the security and military apparatus and the subsequent sectarian war led to chaos in Iraq. Syria also began to have its share of political stalemate in 2011 when Arab uprisings spread its vociferous wing to unseat the Assad regime. The insistence of Syrian regime, to remain in power, led to a protracted conflict that eventually led to massive migration to neighboring countries soon after the eruption of civil war, as discussed in the previous section. In Iraq, the emergence of ISIS and its intensification in June 2014 may well explain the exodus of Iraqis to Europe once again after the big influx of refugees when the sectarian war intensified in 2006 . The 2015 
mass migration and the perilous journey are just the beginning of the accumulated political upheavals in the MENA region. In assessing the factors that led Iraqis and Syrians to venture into the perilous journey as they did in 2015, the researchers are aware that some of these issues are recurrent in the history of migration. What makes the case a different one is the number involved and the daunting spirit of the displaced people and refugees that embarked on such hazardous journey to Europe. Out of 393,532 migrants who arrived by sea between January and September in Greece, 277,899 of them were Syrians (International Organization for Migration, 2015).

Although security may be paramount in the minds of those who intentionally left the shore of their countries for Europe, other factors can adequately explain the reason for migration to Europe. One of such factors is social welfare and benefits in Europe. A young Iraqi Kurd said, "If they [refugees] reach Europe, they escape this misery and if they die on the way, they will finally find peace... I am sick and tired of not being able to make a living... I don't care if I die on the way... I want to go to Europe and live like a human being" (Hawramy, 2015). Such is the extent of desperation on the part of refugees who are thinking about fleeing to Europe in 2015.

Related to this complicated situation in Middle East countries are the issues of citizenship and social welfare. Most of the migrants from Iraq and Syria noted with dismay that it might not be possible for them to return to their respective countries again and as such needed a country that can accommodate them together with their family (Arango, 2015). Most of them seem to be concerned with either getting residential status or citizenship for their children and the unborn. The social welfare package may also explain why most of the refugees and displaced people turned their back to most countries in Asia and Africa and headed to Europe for better social benefits.

The desperate bid on the part of parents to ensure the children get better living condition is also an important reason that propelled them to move. One scholar aptly described Syrian children conditions in neighboring countries as having "no future" as "three million of them do not go to school; they are malnourished, many sick, many die - miserable deaths, in unsanitary refugee camps....Many of them "are being abused, exploited, mistreated physically and mentally" (Keonig, 2016).Some parents who are wary of the future of their children were also forced to leave. On September 10, 2015, UNICEF Regional Director for the MENA said that "every Syrian I spoke to has told me that they would have stayed in their own country if they were able to feel safe, live in peace, and be treated with dignity." He added, "people risk their lives and the lives of their children to flee to Europe because they have no other option and they see no future for themselves or for their children" (UNICEF, 2015). By the same token, a Syrian mother in Turkey also stated: "for me, I have no hope, but for my children, may be" (Frelick, 2015).

Besides, other factors can also be advanced to explain the rationale for enmass migration of Syrians and Iraqis to Europe. One of such is the availability of job opportunities. As stated earlier, one of the enduring issues that make migration inevitable is the lack of job opportunities in most developing countries. In Iraq, youth unemployment stands at 18 percent. Ironically, the rate is even higher among those with higher education who are more prone to migrate (Hawramy, 2015). Also, poverty has become a major issue in Iraq including Kurdistan Region which has fairly done better in previous years but certainly not in 2015 onward. The necessity to improve one's living condition which depends on the availability of a good job may permanently become a crucial issue in the contemporary global social landscape. Migration may be inevitable, even without civil war, repression, and conflict at home, to arrest the socioeconomic malaise. The tendency to migrate is inherent in the natural instinct of man for survival, and this may well explain the reason why the history of human being is replete with migration and constant mobility. In Iraq and Syria cases, this has led to what may be termed as snowball and copycat effect. Syrian and Iraqi refugees in neighboring countries track migrants on "messaging apps like Viber and WhatsApp and hear back from friends who have reached places like Germany where Chancellor Angela Merkel has welcomed migrants" (Arango, 2015). 
The stories refugees hear from relatives in Europe are often euphoric, and full of possibilities resulting in many people migrating from neighboring countries to Western Europe.

Another possible factor for feeling hopeless is the Western "soft and relaxed" attitude and approach to ISIS, at least in 2015. In early September 2014, John Kerry, the US Secretary of State said "it may take a year, it may take two years, it may take three years [to destroy ISIS]....But we're determined it has to happen" (Schmitt, Gordon and Cooper, 2014). By the same token, in the same month, Barak Obama, the then US President, stated "it will take time to eradicate a cancer like ISIS" (The New York Times, 2014). Almost a year after the US declaration of war on ISIS, in July 2015, the US Army Chief of Staff General Odierno asserted that "defeating Islamic State militants could take 10 to 20 years" (Mehta, 2015). All these external lamentations, assessments and declarations intensified the hopelessness in the mind of the Syrian and Iraqi refugees in neighboring countries, which tended to dictate the perilous journey to Europe in 2015. How would one expect people to suffer for another ten years in the midst of chaos and anarchy? One year after the war and with over 7,331 airstrikes into the campaign against ISIS in Syria and Iraq, ISIS is yet not defeated. The only forces that can defeat, hold on ground and push ISIS back are the Kurds in Iraq and Syria. The Western coalition and regional powers not only hesitant to support the Kurds directly but they do everything to limit their power. It may, therefore, be right to say that economic prosperity, hopelessness, coupled with the need for survival and security, are the important propellant for Syrians and Iraqis to embark on a dangerous journey to Europe.

In addition to the above mentioned factors, in Lebanon, a hosting refugee country, several obnoxious regulations are in place which make life more unbearable for refugees living there (Malsin, 2015). Most of refugees are not allowed to work and are required to promise as such through documentary evidence. Also, each refugee must renew its stay every year, which amount to US\$200.00 (UNHCR, 2015). The same procedure also applies to refugees in Jordan, which is conducted through verification exercise. All these unwarranted procedures make staying in neighboring countries a difficult task. In this way, there is no sense of belonging in the society as opposed to what obtains in some European countries. Most European countries hold the principle of good governance, which is premised on social justice, dearly. Such allows foreigners to enjoin the same rights as citizens of European Union. Thus, most Iraqis and Syrians are aware of the fact that if they should eventually arrive Europe from their refugee camps, their lives will be relatively secured given the social structure available, which takes care of the right of each group inhabiting each state in Europe.

The limited capacity of neighboring countries to provide for the needs of refugees is another reason for the mass exodus of refugees to Europe in 2015. In 2015, Turkey had nearly 2 million Syrians refugees, more than three times the number at the beginning of 2014. Turkey, which is seen as the best-equipped country in the region, in 2015 it had only 130,000 out of some 600,000 school-age Syrian refugee children attending school (Kirisci and Ferris, 2015). Lebanon, an exceptionally small country just of 10 thousand kilometer square with 4.8 million people, in 2015, was hosting 1.1 million Syrian refugees (UNICEF, 2015). Similar to Turkey, in 2015, almost 200,000 Syrian children were out of school in Lebanon. What has worsened the conditions of refugees is that Lebanon forbids the construction of formal refugee camps. Consequently, around 40 percent of refugees live in makeshift shelters including "garages, worksites, one room structures and unfinished housing" (Amnesty International, 2014). Similarly, in 2015, Jordan was hosting almost 630,000 Syrian refugees. Reports indicated that overwhelming majority of them considering heading to Europe as Jordon faces refugee crisis (Spencer and Sanchez, 2016). Although Kurdistan Region of Iraq has been a source of refugees since 2015, it was hosting 1.5 million displaced Iraqis and 280,000 Syrian refugees in the same year (Kurdistan Regional Government, 2015). However, since mid-2015 Kurdistan Regional Government has been suffering from the financial crisis which incapacitates it from even making monthly salaries and allowances to its 1.3 million civil servants (Lake, 2015). Egypt, the most populated Arab country was hosting only 122,375 Syrian refugees in 2015. Despite, reports claim 
that state repression and deportation is part of what is compelling Syrians to risk the sea route to Europe (Refugees International, 2014). In short, the lack of infrastructure, as well as structural assurance in the host countries coupled with the total breakdown of law and order in Syria and Iraq, is thus a culprit for such great trek to Europe.

Also germane in this case is the failure of Arab-oil rich Gulf States to proffer immediate solutions to the problem of refugees in the Middle East. Regarding the provision of tentative asylum and refugee camps to displaced Syrians and Iraqis, Saudi Arabia, Qatar, Kuwait, and the United Arab Emirates failed woefully in this respect. Ironically, Saudi Arabia has 100,000 air-conditioned tents with full sanitary services that can house 3 million people at once. It is the only country that could make an immediate change to the Syrian and Iraqi refugees. All these tents sitting empty as Saudi Arabia has taken zero refugees (Mchugh, 2015). If they had done the necessary, the story might be different by now. But the lackluster of these countries coupled with their unfriendliness, regarding stringent immigration policy, made Europe appealing to most Syrians and Iraqis. With the exception of the Gulf States, most countries in the region share more or less the burden of Syrian and Iraqi refugees including Turkey, Lebanon, Jordan, Kurdistan Region of Iraq and to a lesser extent, Egypt. Some of these countries, which harbor most of the refugees, lack functional infrastructures like school, hospitals and welfare house to cater for the need of the refugees from affected countries (Dunn, 2015; Dahl, 2014). What one expects of some of these Arab Gulf countries is to be their brother's keeper and incidentally they become bystanders in the issue. It needs to be stressed here that Saudi Arabia claimed it already has over 500,000 Syrians within its border but such claim could not be confirmed given the process involve in obtaining a visa (Malsin, 2015). Given the affinity, regarding culture, language and belief system that exist naturally among virtually all Arab countries it is expected that those enjoy relative peace and stability within their borders should rise to the occasion to rescue the Syrians and Iraqis. If most of these Arab countries have lent a helping hand, possibly those perished in the Mediterranean seas might still be alive.

In the case of some of the oil-rich Gulf countries, there exists an assumption that the refugee from Syria and Iraq may alter the social landscape in those countries most especially in Qatar, United Arab Emirates, Bahrain, Kuwait and Oman (Recknagel, 2015). As far as demography is concerned, these countries are very small but have resources that can cater for the additional millions population. But for the fear that the society is already populated by expatriates from various countries, most of these countries turned their back at an auspicious time to assist the refugees from Syria and Iraq. Any reason provided, to harbor refugees from all these countries, contradicts moral and ethical reasoning.

Furthermore, the low level of European Union resettlement of refugees might also be one of the culprits for mass migration to Europe in 2015. By August 2015, there were a little over 100,000 places made available for resettlement, an amount corresponding to less than three percent of the overall number of Syrian refugees (Kirisci, 2015). The longer wait, as well as complicated resettlement procedure with attendant red tape, frustrated many Syrians and Iraqis in the neighboring countries to flee to a different direction to reach Europe. The hopelessness some refugees have endured for many months, if not say years, in neighboring countries and within Syria and Iraq forced them to risk their journey to Europe. In 2015, for example, 1.55 million Syrian refugees were newly registered, but only 96,100 were granted international protection on an individual basis (HRW, 2015). HRW pointed out that "in 2015, globally, 960,000 people were in need of resettlement, including 316,000 in the Middle East" (HRW, 2015). However, the UNHCR reported that it "has the staff capacity to process only about 70,000" (HRW, 2015). The comatose percentage of refugees taken in by European countries no doubt explains the hopelessness in embarking on a perilous journey to Europe by the refugees. It may, therefore, right to assert that there are overwhelming factors that forced the Syrians and Iraqis out of their geographical confine to seek for greener pasture elsewhere outside the Middle East. In this way, most of them headed to Europe. 


\section{CONCLUSION}

From the above, it is clear that many factors can be advanced in explaining the mass exodus of refugees to Europe in 2015. These factors are broadly grouped into two categories: endogenous and exogenous factors. Endogenous factors include unending conflicts in both countries, sectarian and ethnic cleansing committed by various warring factions, the breakdown of societal fabric, complete destruction of cities and towns, the conditions for children, and the attendant loss of hope. The exogenous factors highlighted in this research are the capacity of neighboring countries, the apathy of the Gulf-oil rich Arab countries, the low number of European Union resettlement of refugees, the Western approach to ISIS, and economic and social justice in Europe. It needs to be stated here that all these factors have not affected the mass exodus of Iraqis and Syrians in the same way. According to this research, the most compelling reasons for "forceful" migration to Europe in 2015 are the unending conflict and loss of hope arising from the breakdown of a means of making a livelihood. Human beings have been found capable of surviving in chaotic and anarchical environments. Nevertheless, once the means of basic survival is truncated or threatened, humans are forced to migrate. This is the case in Syria and Iraq. People have been enduring the situation there for years but the complicated economic and financial woes have compelled people to seek an alternative life elsewhere. This is exactly what happened in 2015.

The influx of refugees from Syria and Iraq to Europe represents one of the most important episodes in the history of refugee crises witnessed by the world since the 1940s. Such an episode will go down in history as the most complicated of all refugee crises given its seemingly endless nature. What is most difficult is the ongoing irresolvable civil war in Syria and Iraq. If the situation persists for another two years, then possibly nobody would want to remain there risking their lives. If this submission is correct then the world should expect more refugee crises in 2016 and beyond, as more displaced people will want to join the "great trek" to Europe. The only tentative solution to the refugee crisis is for countries in the Gulf to respond to the crisis for it may even consume them. Another possible solution is the need to find a solution to the Syrian and Iraqi political crisis by the local stakeholders as well as by the international and regional players. At the same time, they have to effectively and swiftly deal with ISIS and other terrorist groups such as Jabhat al-Nusra.

\section{REFERENCES}

Al Hendi, Ahed. (2011). "The Structure of Syria's Repression: Will the Army break with the Regime?" Foreign Affairs, May 3, from https://www.foreignaffairs.com/articles/middle-east/2011-0503/structure-syrias-repression (accessed April 7, 2016).

Aljazeera. (2016). "UN: Destruction of Ramadi worse than anywhere in Iraq." March 4. From http:/ / www.aljazeera.com/news/2016/03/destruction-ramadi-worse-iraq160304182242699.html (accessed April 7, 2016).

Amnesty International. (2014). "Left Out in the Cold: Syrian refugees abandoned by the international community", from https://www.amnesty.org.nz/sites/default/files/Left_Out_In_The_Cold_0.pdf (accessed April 12, 2016).

Anderson, Lisa. (2011). "Demystifying the Arab spring." Foreign Affairs, vol. 9, no. 3, pp. 2-7.

BBC News. (2015). "Syria conflict: Number of refugees passes four million." from http:/ / www.bbc.com/news/world-middle-east-33457886 (accessed April 9, 2016).

BBC News. (2016a). "Migrant crisis: Migration to Europe explained in seven charts." March 4, from http:/ /www.bbc.com/news/world-europe-34131911 (accessed April 7, 2016).

Bengali, Shashank. (2014). "In Iraq, some Kurds accuse Arab neighbors of turning against them." Los Angeles Times, September 8.

Bradley, Matt and Nabhan Ali A. (2013). "Iraq Raids Protesters' Camp." The Wall Street Journal, April 23.

Bradley, Matt. (2014). "In Climate of Growing Fear, Iraqis Flee to Safer Ground." The Wall Street Journal, January 1. 
Cockburn, Patrick. (2016). "The Arab Spring, five years on: A season that began in hope, but ended in desolation." The Independent, January 9.

Cohen, Robin. (1995). The Cambridge Survey of World Migration. Cambridge: Cambridge University Press.

Dahi, Omar. (2014). "Syrian refugees and the regional crisis." Carnegie Middle East Centre, December 30, from http:/ / carnegieendowment.org/sada/?fa=57622 (accessed April 11, 2016).

Dunn, Elizabeth. (2015). "The Failure of Refugee Camps." Boston Review, September 28, from https://bostonreview.net/editors-picks-world/elizabeth-dunn-failure-refugee-camps (accessed April 11, 2016).

Economist. (2014). "Iraqi Christians and the West: A rock and a hard place." July 14, from http://www.economist.com/blogs/erasmus/2014/07/iraqi-christians-and-west (accessed April 11, 2016).

Fathalla, Amira. (2015). "Migrant crisis: Why Syrians do not flee to Gulf States." September 2, from http:/ / www.bbc.com/news/world-middle-east-34132308 (accessed April 11, 2016).

Frelick, Bill. (2015). "Why don't Syrians stay in Turkey?" Human Rights Watch, September 29, from https://www.hrw.org/news/2015/09/29/why-dont-syrians-stay-turkey (accessed April 11, 2016).

Garfinkle, Adam. (2013). "How to think about the Middle East before the 'Arab Spring' and after." Foreign Policy Research Institute, from http://goo.gl/e3P3LK (accessed April 7, 2016).

Griswold, Eliza. (2015). "Is this the End of Christianity in the Middle East?" The New York Times Magazine, July 26.

Hawramy, Fazel. (2015). “Death no deterrent for Iraqi Kurds wanting better life in Europe." Al-Monitor, October 1.

Hayward, John. (2015). “US Intel Chief: Iraq and Syria may be finished as nations." September 15, from http:/ /goo.gl/5ZtCRo (accessed April 7, 2016).

HRW. (2015). "Europe's refugee crisis: An agenda for action." Human Rights Watch, November 16, from https:/ /www.hrw.org/node/283398 (accessed April 11, 2016).

HRW. (2016a). "Syria: Justice Needed for 5 Years of Abuses." Human Rights Watch, March 14, from https://www.hrw.org/news/2016/03/14/syria-justice-needed-5-years-abuses (accessed April 7, 2016).

HRW. (2016b). "Iraq: Possible War Crimes by Shia Militia." Human Rights Watch, January 31, from https://www.hrw.org/news/2016/01/31/iraq-possible-war-crimes-shia-militia (accessed April 9, 2016).

IDMC. (2016). "Iraq IDP Figures Analysis." Internal Displacement Monitoring Centre, from http:/ / www.internal-displacement.org/middle-east-and-north-africa/iraq/figures-analysis. (accessed April 7, 2016).

International Organization for Migration. (2015). “Mediterranean Update Migrant Deaths Rise to 3,329 in 2015." December 30, from https:/ / www.iom.int/news/mediterranean-update-migrantdeaths-rise-3329-2015 (accessed April 11, 2016).

Iraq Body Count. (2016). "The public record of violent deaths following the 2003 invasion of Iraq." from https:/ / www.iraqbodycount.org/ (accessed April 9, 2016).

Keonig, Peter. (2016). "The Children of Syria." Information Clearing House. from http://www.informationclearinghouse.info/article44491.htm (accessed April 7, 2016).

Kirisci, Kemal and Ferris Elizabeth. (2015). "Not Likely to Go Home: Syrian Refugees and the Challenges to Turkey and the International Community." Brookings Institute, from http://www.brookings.edu/ /media/research/files/papers/2015/09/syrian-refugeeinternational-challenges-ferris-kirisci/turkey-policy-paper-web.pdf (accessed April 12, 2016).

Kirisci, Kemal. (2015). "Why 100,000s of Syrian refugees are fleeing to Europe." Brookings Institute. September 3, from http:/ / www.brookings.edu/blogs/order-from-chaos/posts/2015/09/03-eurefugee-crisis-kirisci (accessed April 11, 2016).

Kirmanj, Sherko. (2013). Identity and Nation in Iraq. Boulder, CO: Lynne Rienner Publishers. 
Kurdistan Regional Government. (2015). “Official statement on the current humanitarian situation in the Kurdistan Region." from http://austria.krg.org/en/offizielle-stellungnahme-zur-aktuellenhumanitaren-lage-in-der-region-kurdistan/ (accessed April 12, 2016).

Lake, Eli. (2015). “Crisis Looms for Refugees taken in by Iraq's Kurds.” Bloomberg View, September 20.

Malsin, Jared. (2015). "Why Some Arabs States Refuse to accept Syrian Refugees." Time, September 8, from http:/ / time.com/4025187/arab-states-syrian-refugees/ (accessed April 11, 2016).

Mamouri, Ali. (2014). "Diversity and religious pluralism are disappearing amid Iraq's crisis." The Conversation, August 4, from http:/ / theconversation.com/diversity-and-religious-pluralism-aredisappearing-amid-iraqs-crisis-29832 (accessed April 11, 2016).

Mamouri, Ali. (2015) "Iraq sees exodus of minorities." Al-Monitor, September 17.

Mchugh, Jess. (2015). “Refugee Crisis 2015: Saudi Arabia Criticized for 100,000 Air-Conditioned Tents Not in Use." International Business Times, September 14, from http://www.ibtimes.com/refugee-crisis2015-saudi-arabia-criticized-100000-air-conditioned-tents-not-use-2095403 (accessed April 11, 2016).

Mehta, Aaron. (2015). "Odierno: ISIS Fight will last '10 to 20 Years'." Defense News, July 17, from http://www.defensenews.com/story/defense/2015/07/17/odierno-isis-fight-last-10-20years/30295949/ (accessed April 11, 2016).

Nichols, Brian. (2015). "The Humanitarian Crisis in Iraq: Internal Displacement." The Education for Peace in Iraq Center, October 14, from http://goo.gl/Rcc6Qv (accessed April 9, 2016).

Recknagel, Charles. (2015). "Why Don't Rich Arab Gulf States Welcome Syrian Refugees?" from http:/ / www.rferl.org/content/why-dont-rich-arabs-welcome-syrian-refugees/27227458.html (accessed April 11, 2016).

Refugees International. (2014). “Tough Times for Syrian Refugees in Egypt." May 18, from http:/ / www.refugeesinternational.org/reports/2015/10/14/tough-times-for-syrian-refugeesin-egypt (accessed April 12, 2016).

Schmitt, Eric, Gordon Michael and Cooper Helene. (2014). “Destroying ISIS May Take Years, U.S. Officials Say." The New York Times, September 7.

Sinder, Sara. (2015). "Christians are disappearing from the Middle East." CNN, December 25, from http:/ / edition.cnn.com/2015/12/25/world/isis-refugees-christmas/ (accessed April 9, 2016).

Spencer, Richard and Sanchez Raf. (2016). "Half a million Syrians in Jordan considering heading to Europe as country faces refugee crisis." The Telegraph, February 2.

Taub, Amanda. (2015). "Europe's refugee crisis, explained." VoxExplainer, from http:/ / www.vox.com/2015/9/5/9265501/refugee-crisis-europe-syria (accessed April 7, 2016).

The New York Times. (2014). "Transcript of Obama's remarks on the fight against ISIS." September 10, from http://www.nytimes.com/2014/09/11/world/middleeast/obamas-remarks-on-thefight-against-isis.html (accessed April 10, 2016).

UNHCR. (2014). "Global trends, forced displacement in 2014." United Nation High Commissioner for Refugees, from http://unhcr.org/556725e69.html (accessed April 12, 2016).

UNHCR. (2015). "Seven factors behind movement of Syrian refugees to Europe." United Nation High Commissioner for Refugees, from http://www.unhcr.org/560523f26.html (accessed April 12, 2016).

UNICEF. (2015). "Press release by United Nations Children's Fund." September 10, from http:/ / www2.unicef.org:60090/media/media_83168.html (accessed April 12, 2016).

Wintour, Patrick. and Ackerman Spencer. (2016). "Syria peace talks stall amid dispute over 'federal Syria' call." The Guardian, March 16.

Yong, G. A., \& Pearce, S. (2013). A Beginner's Guide to Factor Analysis: Focusing on Exploratory Factor Analysis, Tutorials in Quantitative Methods for Psychology, 9(2), pp-79-94. 